\title{
Tree Patches Show Greater N Losses but Maintain Higher Soil N Availability than Grassland Patches in a Frequently Burned Oak Savanna
}

\author{
Feike A. Dijkstra, ${ }^{1 *} \uparrow$ Keith Wrage, ${ }^{2}$ Sarah E. Hobbie, ${ }^{1}$ and Peter B. Reich ${ }^{2}$ \\ ${ }^{1}$ Department of Ecology, Evolution, and Behavior, University of Minnesota, St. Paul, Minnesota 55108, USA; ${ }^{2}$ Department of Forest \\ Resources, University of Minnesota, St. Paul, Minnesota 55108, USA
}

\begin{abstract}
Long-term prescribed fires have increased woody canopy openness and reduced nitrogen $(\mathrm{N})$ cycling (that is, net $\mathrm{N}$ mineralization) in an oak savanna in Minnesota, USA. It is unclear how fire-induced shifts from oak-dominated to C4 grass-dominated vegetation contribute to this decline in $\mathrm{N}$ cycling compared to direct effects of increasing fire frequency promoting greater $\mathrm{N}$ losses. We determined (1) the magnitude of decline in net $\mathrm{N}$ mineralization in oak versus grass-dominated patches with increasing fire frequency and (2) if differences in net $\mathrm{N}$ mineralization between oak and grass patches in frequently burned oak savanna (burned 8 out of 10 years on average during the last 40 years) could be attributed to differences in $\mathrm{N}$ losses through volatilization and leaching or to plant traits affecting decomposition and mineralization. In situ net $\mathrm{N}$ mineralization declined with increasing fire frequency overall, but this decline was less in oakthan in grass-dominated patches, with oak-dominated patches having more than two times higher net $\mathrm{N}$ mineralization than grass-dominated patches. Greater net $\mathrm{N}$ mineralization in oak-dominated patches occurred despite greater $\mathrm{N}$ losses
\end{abstract}

through volatilization and leaching (on average 1.8 and $1.4 \mathrm{~g} \mathrm{~m}^{-2} \mathrm{y}^{-1}$ for oak- and grass-dominated patches, respectively), likely because of higher plant litter $\mathrm{N}$ concentration in the oak-dominated patches. As total soil $\mathrm{N}$ pools in the first $15 \mathrm{~cm}$ did not differ between oak- and grass-dominated patches (on average $83 \mathrm{~g} \mathrm{~N} \mathrm{~m}^{-2}$ ), $\mathrm{N}$ inputs from atmospheric deposition and uptake from deep soil layers may offset higher $\mathrm{N}$ losses. Our results further show that net $\mathrm{N}$ mineralization rates decline within 5 years after tree death and subsequent colonization by $\mathrm{C} 4$ grasses to levels observed in grass-dominated patches. Although long-term prescribed fires often directly reduce $\mathrm{N}$ stocks and cycling because of increased $\mathrm{N}$ losses, this study has shown that fire-induced shifts in vegetation composition can strongly contribute to the declines in $\mathrm{N}$ cycling in systems that are frequently disturbed by fires with potential feedbacks to plant productivity.

Key words: cedar creek; dissolved organic $\mathrm{N}$ (DON); grasses; net $\mathrm{N}$ mineralization; $\mathrm{N}$ leaching; $\mathrm{N}$ volatilization; oak savanna; prescribed fires; total soil N; trees.
Received 14 January 2005; accepted 1 April 2005; published online 13 April 2006.

*Corresponding author; e-mail: dijkstra@ucsc.edu

†Department of Environmental Studies, University of California, Santa Cruz, 1156 High Street, Santa Cruz, California 95064, USA

\section{INTRODUCTION}

Alterations in fire frequency have significant effects on primary productivity and carbon (C) and nitrogen $(\mathrm{N})$ cycling in terrestrial ecosystems (Tilman and others 2000; Reich and others 2001; Wardle and 
others 2003) with potentially large ramifications for the global C cycle and climate system (Houghton and others 2000; Tilman and others 2000; Hurtt and others 2002). Reduced C and N cycling with increased fire frequency have been linked to longterm effects of fire on $\mathrm{N}$ losses, promoting production of plant litter with low $\mathrm{N}$ concentration that slows down decomposition and net $\mathrm{N}$ mineralization (Ojima and others 1994; Blair 1997). Fire frequency also affects the spatial and temporal dynamics of woody and herbaceous plant composition (Huddle and Pallardy 1996; Scholes and Archer 1997; Peterson and Reich 2001; Briggs and others 2002), and both models and experimental evidence suggest that shifts in woody and herbaceous plant composition contribute to altered $\mathrm{C}$ and $\mathrm{N}$ cycles in systems that are burned either more frequently or less frequently than in the past (Daly and others 2000; Reich and others 2001). However, it is unclear how fire-induced shifts in woody and herbaceous plant composition affect $\mathrm{C}$ and $\mathrm{N}$ cycling compared to direct effects of fire on $\mathrm{N}$ losses.

Fire can alter primary productivity and the spatial pattern and abundance of herbaceous and woody vegetation by directly influencing the availability of nutrients. Fire causes losses of nutrients via volatilization (Raison and others 1985; Cook 1994), and often, fire enhances losses of nutrients through leaching and runoff (Wright 1976; Chorover and others 1994; Dodds and others 1996). Nitrogen volatilizes at a relatively low temperature $\left(>65^{\circ} \mathrm{C}\right)$ and $\mathrm{N}$ volatilization losses with fire are generally much higher than for other nutrients such as phosphorus, potassium, calcium, and other cations (Cook 1994) that volatilize at higher temperatures. Although fire usually enhances $\mathrm{N}$ mineralization in the short term (Hobbs and Schimel 1984; Schoch and Binkley 1986), losses of $\mathrm{N}$ through frequent burning can ultimately lead to long-term decreases in $\mathrm{N}$ availability (Ojima and others 1994; Blair 1997; Turner and others 1997; Fynn and others 2003).

Losses of $\mathrm{N}$ with fire will depend on species composition. Plant species that produce relatively high amounts of $\mathrm{N}$ in aboveground litter are likely to lose more $\mathrm{N}$ through volatilization than plant species with low amounts of $\mathrm{N}$ in aboveground litter when this litter is burned (Boerner 1982). Thus, in ecosystems where primary productivity is $\mathrm{N}$ limited, fire should put a greater constraint on primary productivity for plant species that produce more $\mathrm{N}$ than of plants that produce less $\mathrm{N}$ in aboveground litter.

It is well known that plant species influence nutrient cycling and soil nutrient availability through their effects on litter decomposition and nutrient uptake, input and loss (Hobbie 1992; Eviner and Chapin III 2004). In savannas, higher $\mathrm{N}$ availability in soils under tree crowns than in soils under surrounding grassland communities have been attributed to increased inputs of atmospheric $\mathrm{N}$ deposition under tree crowns (Kellman 1979; Bernhard-Reversat 1982), increased inputs of $\mathrm{N}$ from animal droppings (Belsky 1994), increased $\mathrm{N}$ input from plant litter under tree crowns because of extended $\mathrm{N}$ uptake of woody plants from open grassland (Belsky 1994), and to higher rates of soil $\mathrm{N}$ turnover because of greater inputs of carbon substrates that support greater microbial activity and turnover (Herman and others 2003), or because of improved micro-climate (for example, soil moisture) below the tree crown (Bernhard-Reversat 1982; Belsky and others 1989; Wilson and Kleb 1996).

It is unclear if differences in $\mathrm{N}$ availability (that is, net $\mathrm{N}$ mineralization) between woody and herbaceous vegetation in frequently burned systems are caused by differences in $\mathrm{N}$ losses that result from fire, or are mediated by fire-independent plant traits affecting inputs and internal recycling of N. More than 25 prescribed fires during a 32-year period in an oak savanna in Minnesota, USA, reduced overall rates of net $\mathrm{N}$ mineralization, net primary productivity and pools of $\mathrm{N}$ in aboveground biomass (Reich and others 2001). However, whether these patterns differed between oak- and grass-dominated patches within frequently burned sites was not determined. Here we tested the magnitude of decline in net $\mathrm{N}$ mineralization in oak- versus grass-dominated patches, and whether three alternative mechanisms may have caused oak-dominated patches to have greater net $\mathrm{N}$ mineralization than grass-dominated patches: (1) oak tree patches lose less $\mathrm{N}$ through volatilization and leaching than grassland patches, despite having greater amounts of $\mathrm{N}$ in aboveground litter (fire-plant interaction effect), (2) oak trees have plant traits that maintain relatively high net $\mathrm{N}$ mineralization rates independent of the effect of fire (plant effect), and (3) oak tree patches occur on intrinsically more $\mathrm{N}$-rich soils than grassland patches (soil effect). Here we study these possible effects on soil $\mathrm{N}$ mineralization in a frequently burned oak savanna in Minnesota, USA.

\section{Methods}

\section{Study Site and Sampling Plots}

We did our research in an oak savanna located on a sandy glacial outwash plain in the Cedar Creek Natural History Area, Minnesota, USA. The terrain 
is relatively flat with excessively drained sandy soils that are extremely poor in organic matter content (Typic and Alfic Udipsamments). Mean annual precipitation is $790 \mathrm{~mm}$ with mean monthly temperatures of $-11^{\circ} \mathrm{C}$ in January and $22^{\circ} \mathrm{C}$ in July.

Aerial photos indicate that our study site was predominantly inhabited by woodland vegetation with scattered grass community patches prior to the burn treatments that started in 1964. Nineteen units ranging between 2.4 and 30 ha were burned at frequencies ranging between 0 and 0.84 fires per year. As a consequence, units that received no fires since 1964 have become increasingly dominated by oak tree vegetation, while units with the highest fire frequencies show reduced dominance of oak trees (Peterson and Reich 2001) and are now characterized by small patches of oak trees (mostly northern pin oak, Quercus ellipsoidalis E. J. Hill, and bur oak, Quercus macrocarpa Michx.) and large open spaces dominated by herbaceous plants, especially C4 grasses and sedges (for example, Andropogon gerardii, Schizachyrium scoparius, Sorghastrum nutans, Poa pratensis, and Carex spp.). We selected the two burn units with the highest fire frequency for this study, which showed clear oak- and grass-dominated patches.

Prescribed burns were usually conducted in April and May, after snowmelt, using a strip head-fire technique (Irving 1970). Burning conditions included air temperatures of $15-25^{\circ} \mathrm{C}$, relative humidity of $25-45 \%$ and winds less than $20 \mathrm{kph}$. Fire behavior varied with weather conditions and fuel loads, but fires were generally of low intensity, with mean flame height less than $1 \mathrm{~m}$, typically burning all of the surface area (F. A. Dijkstra, personal observation).

In 1995, we established 16 transects of variable length (ranging between 6 and $20 \mathrm{~m}$ ) in one of the two burn units with the highest fire frequency (0.84 fires/y, unit 104, 'transect study'). Transects originated at the center of a cluster of 3-6 oak trees (8 transects) or at the stem of an individual large oak tree (4 with Q. ellipsoidales and 4 with Q. macrocarpa) and ended in an open area dominated by herbaceous vegetation. In the transect study in situ net $\mathrm{N}$ mineralization and losses of aboveground litter through burning were measured (see below).

In 2001 we selected 12 plots $(5 \times 5 \mathrm{~m})$ dominated by Q. ellipsoidales ('savanna-tree' plots) and 12 plots dominated by herbaceous vegetation, mostly grasses ('savanna-grass' plots), equally divided in the two burn units with the highest fire frequency (0.84 fires/y, units 103 and 104). Savanna-tree plots consisted either of a cluster of 3-6 trees or large single trees $(\mathrm{DBH}>25 \mathrm{~cm})$ of Q. ellipsoidales with herbaceous vegetation growing in the under-story. The center of a savanna-grass plot was always further than $15 \mathrm{~m}$ away from the nearest living tree. We also selected six plots in two units (109 and 110) that were not burned since 1964 ('unburned forest' plots, three plots in each unit) and dominated by $Q$. ellipsoidales trees with little under-story growth. In the unburned forest plots, savanna-tree and savanna-grass plots we measured in situ net $\mathrm{N}$ mineralization, potential net $\mathrm{N}$ mineralization in the laboratory, losses of $\mathrm{N}$ through leaching and burning of aboveground litter, aboveground litter $\mathrm{N}$ and root $\mathrm{N}$ concentration, and short-term changes in inorganic $\mathrm{N}$ pools caused by fire.

In 2002 we selected additional plots in the vicinity of dead trees to determine whether oak trees were growing in patches with inherently different $\mathrm{N}$ mineralization and thereby responding to, rather than causing, differences in soil $\mathrm{N}$ cycling. In 1984, 1990, 1995, and 2000 tree surveys were carried out in which all living and dead trees were recorded in a $50 \times 75 \mathrm{~m}$ grid in each unit (Peterson and Reich 2001). Using these surveys we selected dead tree plots where Q. ellipsoidales or Q. macrocarpa trees died between 1984 and 1990 (dead90), between 1990 and 1995 (dead95), and between 1995 and 2000 (dead00). Each dead tree plot consists of one large dead tree $(\mathrm{DBH}>25 \mathrm{~cm})$ or a number of trees that died during the same period. The nearest living tree was at least $10 \mathrm{~m}$ away from the center of each plot. Because of a limited number of suitable plots we were unable to balance the number of plots in each unit; there are 2 dead90, 3 dead95, and 3 dead00 plots in unit 103, and 2 dead90, 1 dead95, and 1 dead00 plots in unit 104 . In the dead tree plots we measured net and potential $\mathrm{N}$ mineralization, and root $\mathrm{N}$ concentration.

\section{SAmpling ANd Analyses}

\section{Net N Mineralization}

We measured in situ net $\mathrm{N}$ mineralization to $15 \mathrm{~cm}$ soil depth using a modified semi-open core incubation technique (Wedin and Tilman 1990). In the transect study net $\mathrm{N}$ mineralization was measured from June 20 to August 28, 1995 (two incubations) and from June 13 to August 14, 1996 (two incubations). We incubated one soil core (diam. $2.5 \mathrm{~cm}$ ) every $2 \mathrm{~m}$ along transects starting at a cluster of trees and every $1 \mathrm{~m}$ along transects starting at a single oak tree. In the unburned forest, savannatree, and savanna-grass plots we incubated three soil cores in each plot during the period of May 15October 17, 2002 (five incubations, each lasting 
approximately 30 days). In these plots we also did one long incubation over the winter from October 17, 2002 to May 17, 2003. For each of these plots the three samples were pooled. We sieved $(2 \mathrm{~mm})$ incubated soil cores, as well as an equal number of soil cores taken at the start of each incubation, and extracted them with $1 \mathrm{M} \mathrm{KCl}$. Extracts were analyzed for $\mathrm{NO}_{3}{ }^{-}$and $\mathrm{NH}_{4}{ }^{+}$on an Alpkem auto-analyzer. We measured soil moisture content on a subsample by oven drying $\left(48 \mathrm{~h}, 105^{\circ} \mathrm{C}\right)$. We calculated net $\mathrm{N}$ mineralization by subtracting initial from final total inorganic $\mathrm{N}\left(\mathrm{NO}_{3}{ }^{-}+\mathrm{NH}_{4}{ }^{+}\right)$. We used soil bulk densities estimated from a regression relationship between soil bulk density and total soil $\mathrm{C}(\%)$ to convert mass-based net $\mathrm{N}$ mineralization to area-based net $\mathrm{N}$ mineralization.

To compare net $\mathrm{N}$ mineralization results in 20022003 with 1995-1996 we used the averaged inner three sampling points of each transect as the equivalent of one savanna-tree plot sample, and the averaged outer three sampling points of each transect as the equivalent of one savanna-grass plot sample. There were no significant differences in net $\mathrm{N}$ mineralization between tree clusters and single trees, or between Q. ellipsoidalis and Q. macrocarpa.

\section{N Losses Through Leaching}

We estimated $\mathrm{N}$ losses through leaching by measuring $\mathrm{N}$ concentrations in soil solutions periodically sampled over a 2 -year period with suction lysimeters (Soilmoisture Inc.) installed at $60 \mathrm{~cm}$ soil depth at a $30^{\circ}$ angle. In the summer of 2001 we installed one lysimeter at each of the unburned forest, savanna-tree, and savanna-grass plots. At the unburned forest and savanna-tree plots lysimeters were $1.5 \mathrm{~m}$ away from the nearest tree trunk. To protect against fires we covered the lysimeters with $60 \mathrm{~cm}$ long PVC pipes (diam. 10 $\mathrm{cm})$ that were coated with fiberglass insulation and galvanized steel pipe.

We collected soil solutions from April 2002 until October 2003. We started with collection as soon as the soils thawed in April and stopped when soils froze up again in October. Sampling occurred directly before and after the prescribed spring fires, and at approximately monthly intervals during the remainder of the season, depending on rainfall events. We evacuated the lysimeters to $50 \mathrm{kPa}$ and emptied them after $24 \mathrm{~h}$ of evacuation. We usually collected more than $200 \mathrm{ml}$ per sample. Samples were immediately transported to the lab and frozen until analyses for dissolved inorganic $\mathrm{N}$ (DIN, $\mathrm{NO}_{3}{ }^{-}$ $+\mathrm{NH}_{4}{ }^{+}$) on an Alpkem auto-analyzer and total dissolved organic $\mathrm{C}$ and total dissolved $\mathrm{N}$ (TDN) on a total organic carbon analyzer with a nitrogen measuring unit attached (Shimadzu TOC- $\mathrm{V}_{\mathrm{CPN}}$ ). We calculated dissolved organic N (DON) concentration as the difference between the TDN and DIN concentration.

We estimated $\mathrm{N}$ losses from leaching below 60 $\mathrm{cm}$ soil depth by multiplying $\mathrm{N}$ concentrations measured in soil solution with daily water fluxes calculated from the hydrological model BROOK90 (Federer 1995) that uses daily values of precipitation, maximum and minimum air temperature as input. We calibrated this model using soil moisture contents that were measured during the growing season of 1995 and 1996 at different soil depths in the transect study (data not shown).

\section{N Losses Through Volatilization}

We estimated $\mathrm{N}$ losses through volatilization as the amount of $\mathrm{N}$ in aboveground plant litter burned by fire minus the spiked increase in inorganic $\mathrm{N}$ in the top $5 \mathrm{~cm}$ of the soil directly after fire. In the spring of 1996 aboveground plant litter was sampled from a $20 \times 50 \mathrm{~cm}$ frame placed at four points (at the two ends, and at half the distance from the center on both sides) along each of the 16 transects directly before and after the fire. In the spring of 2002 we used two $50 \times 50 \mathrm{~cm}$ frames placed randomly at each savanna-tree and savanna-grass plot directly before and after the fire. We clipped and removed all plant material to the ground, sorted, dried and weighed material into oak litter, herbaceous material, and woody debris + acorns. We crushed plant material sampled before the fire with a Wiley mill and finely ground a sub sample with a mixer mill (CertiPrep 8000-D). Samples were analyzed for total N concentration on a Costech 4050 Element Analyzer. We calculated the amount of $\mathrm{N}\left(\right.$ per $\mathrm{m}^{2}$ ) in aboveground litter present before the fire by multiplying $\mathrm{N}$ concentration with mass weight for each litter component. For the transect study in 1996 we used the plant litter measurements at the endpoints, where the endpoint closest to the tree or tree cluster was considered a savanna-tree plot and the other endpoint was considered a savanna-grass plot.

In 2002 we measured the change in surface soil inorganic $\mathrm{N}$ pools $\left(\mathrm{NO}_{3}{ }^{-}\right.$and $\left.\mathrm{NH}_{4}{ }^{+}\right)$caused by fire. One day before and after the fire we sampled three soil cores (diam. $2.5 \mathrm{~cm}$ ) to a depth of $20 \mathrm{~cm}$ at the unburned forest, savanna-tree, and savanna-grass plots. We separated the $0-5$ and $5-20 \mathrm{~cm}$ soil samples with a knife, and pooled the three soil core samples at each plot for the two soil depths. The 0$5 \mathrm{~cm}$ soil samples taken after the fire included the ash from burning at the savanna-tree and savanna- 
grass plots. We processed and analyzed soils for $\mathrm{NO}_{3}{ }^{-}$and $\mathrm{NH}_{4}{ }^{+}$as in the in situ net $\mathrm{N}$ mineralization study.

We calculated the amount of $\mathrm{N}$ lost through volatilization $\left(\right.$ per $\mathrm{m}^{2}$ ) for 2002 by multiplying the $\mathrm{N}$ concentration of litter sampled before the fire with the difference in mass weight before and after burning for each litter component, and subtracting the increase in exchangeable $\mathrm{N}$ in the top $5 \mathrm{~cm}$ of the soil directly after fire, assuming that the increase in exchangeable $\mathrm{N}$ in the soil was caused by ash deposition. To calculate an average annual $\mathrm{N}$ loss through volatilization we adjusted the losses measured through volatilization in 2002 with the fire frequency in the burn units.

\section{Potential Net N Mineralization}

We measured potential net $\mathrm{N}$ mineralization in the top $15 \mathrm{~cm}$ of the soil by incubating soil samples in the laboratory under constant and optimum temperature and soil moisture conditions. In August 2002 we composited three soil cores (diam. $2.5 \mathrm{~cm}$ ) from each of the unburned forest, savanna-tree, savanna-grass, and dead tree plots. Twenty grams of sieved $(2 \mathrm{~mm})$ field-moist soil was placed into a $100 \mathrm{ml}$ filter funnel unit (Pall Microfunnel) where the filter at the bottom of the unit was replaced with a layer of quartz wool. On a sub sample we measured soil moisture content $\left(105^{\circ} \mathrm{C}\right)$. We incubated soils in the dark at room temperature for 268 days, during which the funnel units were covered with a polyethylene film that allows gas exchange but prevents soils from drying out. We leached the soil on days $1,6,16,27,54,83,125$, 188 , and 268 of the incubation. For each leaching we added $40 \mathrm{ml}$ of nanopure water to the funnel unit. After $1 \mathrm{~h}$ we drained the solution from the filter funnel unit using a filter dome (Kontes Ultraware) attached to a vacuum pump set at $20 \mathrm{kPa}$. Solution samples were frozen until analyses for $\mathrm{NO}_{3}{ }^{-}$and $\mathrm{NH}_{4}{ }^{+}$on an Alpkem auto-analyzer. By leaching with nanopure water we may have underestimated $\mathrm{NH}_{4}{ }^{+}$production during the incubation. However, both our in situ and potential net $\mathrm{N}$ mineralization study showed that nitrification was very high in the well-drained sandy soils with more than $95 \%$ of inorganic $\mathrm{N}$ mineralized being nitrified (data not shown).

\section{Root and Total Soil N}

We measured $\% \mathrm{~N}$ in roots that we sieved from the soil samples used for the potential net $\mathrm{N}$ mineralization study. We carefully washed and dried the roots before we ground them with a mixer mill
(CertiPrep 8000-D). We also measured $\% \mathrm{~N}$ in the soil by grinding a sub sample with mortar and pestle. We analyzed \% $\mathrm{N}$ in roots and soils with an Element Analyzer (Costech ECS 4010).

\section{Statistical Analyses}

We tested for significant differences in annual and growing season (June-August) in situ net $\mathrm{N}$ mineralization rates, final cumulative net $\mathrm{N}$ mineralization in the laboratory incubations, annual $\mathrm{N}$ losses through volatilization and leaching, total soil $\mathrm{N}$, aboveground litter $\% \mathrm{~N}$, and root $\% \mathrm{~N}$ among unburned forest, savanna-tree, savanna-grass, and dead tree plots (vegetation type) using one-way analysis of variance (ANOVA). Where there was a significant effect, we compared the means of the different vegetation types using a post hoc Tukey test. We found no significant differences between the two burn units (103 and 104) tested with a nested ANOVA where the effect of the burn units (random factor) was contrasted with vegetation type (fixed factor). Also the unburned units (109 and 110) showed no significant differences. We used repeated-measures MANOVA to test for differences in $\mathrm{N}$ losses through leaching and potential net $\mathrm{N}$ mineralization among vegetation types (between-subject) over time (within-subject). Because of violations of the sphericity assumption, we decreased the degrees of freedom of the F-statistics for the within-subject factor and its interaction with vegetation type using the Geisser and Greenhouse $\varepsilon$ correction factor (Von Ende 2001). All analyses were conducted using JMP (version 4.0.4).

\section{RESUlts}

As found previously, repeated burning was associated with a decline in in situ growing season net $\mathrm{N}$ mineralization rates (and annual rates, see below, Table 1, Reich and others 2001). In 2002, unburned forest plots that were solely dominated by trees had the highest net $\mathrm{N}$ mineralization. In addition, within frequently burned sites, net $\mathrm{N}$ mineralization rates were significantly higher in savanna-tree plots than in savanna-grass plots for both the 1995-1996 and 2002 sampling dates (Table 1). Net $\mathrm{N}$ mineralization declined relatively fast after tree death where the dead tree plots showed very similar net $\mathrm{N}$ mineralization rates as the savanna-grass plots.

Dissolved inorganic $\mathrm{N}$ concentrations measured in lysimeters during the growing season in 2002 and 2003 were lowest for the savanna-tree and savanna-grass plots and highest for the unburned 
Table 1. Average Net $\mathrm{N}$ Mineralization Rates $\left(\mathrm{mg} \mathrm{m}^{-2} \mathrm{~d}^{-1}\right)$ during the Growing ${ }^{\mathrm{a}}$ Season in 1995, 1996 and 2002

\begin{tabular}{|c|c|c|c|}
\hline \multirow[b]{2}{*}{ Treatment } & \multicolumn{3}{|c|}{ Year } \\
\hline & 1995 & 1996 & 2002 \\
\hline Unburned forest & - & - & $40.5(3.6)^{a}$ \\
\hline Savanna-tree & $16.2(3.3)^{\mathrm{a}}$ & $21.2(3.8)^{\mathrm{a}}$ & $26.1(3.0)^{\mathrm{b}}$ \\
\hline Savanna-grass & $8.9(0.9)^{\mathrm{b}}$ & $9.0(1.1)^{\mathrm{b}}$ & $7.2(1.1)^{\mathrm{C}}$ \\
\hline Dead90 & - & - & $10.2(4.5)^{\mathrm{c}}$ \\
\hline Dead95 & - & - & $8.0(0.8)^{\mathrm{C}}$ \\
\hline Dead00 & - & - & $11.7(2.9)^{\mathrm{C}}$ \\
\hline \multicolumn{4}{|l|}{ ANOVA } \\
\hline$P$-value & 0.05 & 0.005 & $<0.0001$ \\
\hline
\end{tabular}

forest plots (Figure 1). DIN concentrations were high after snowmelt and dropped to very low concentrations $\left(<0.05 \mathrm{mg} \mathrm{l}^{-1}\right)$ by the end of June, and stayed low during the remainder of the season in all plots. DIN concentrations were especially high at the start of the growing season in 2003, which coincided with large water fluxes through the soil profile because of snow melt, causing the largest leaching losses of DIN during this time of the year.

In contrast to DIN concentrations, DON concentrations in lysimeters were similar for unburned forest and savanna-tree plots and lowest for savanna-grass plots, and remained fairly stable throughout the growing season in 2002 and 2003. At the end of both growing seasons DON concentrations were 10 (savanna-grass plots) to 20 (unburned forest and savanna-tree plots) times higher than DIN concentrations. Interestingly, we found no pulses in DIN or DON concentrations in the burned plots directly after the spring fires.

There was more $\mathrm{N}$ in aboveground litter before burning and thus a greater potential for $\mathrm{N}$ loss through burning in the savanna-tree plots than in the savanna-grass plots (Figure 2). We only show $\mathrm{N}$ in herbaceous and oak leaf litter, because the amount of $\mathrm{N}$ in woody debris and acorns was relatively small, and not much of this material burned. Herbaceous plants contributed significantly to the amount of aboveground litter $\mathrm{N}$ in the savanna-tree plots, while oak leaf litter blown into grassland plots contributed to the aboveground litter $\mathrm{N}$ in the savanna-grass plots. Because there was significantly more $\mathrm{N}$ in the aboveground litter before burning in savanna-tree than savanna-grass plots both in 1996 and 2002, more N was burned with litter in the savanna-tree than in the savanna- grass plots. However, this was only significant in $2002(P=0.05)$. Burning of litter was less complete in the savanna-tree plots than in the savanna-grass plots. Almost all of the aboveground litter was burned in the savanna-grass plots in both years of recording (on average $95 \%$ for 1996 and $98 \%$ for 2002 ), but only 82 and $64 \%$ was burned in the savanna-tree plots in 1996 and 2002, respectively. Burning of litter in the savanna-tree plots also tended to be more variable than in the savannagrass plots.

Exchangeable inorganic $\mathrm{N}$ (primarily $\mathrm{NH}_{4}{ }^{+}$) in the top $5 \mathrm{~cm}$ of the soil (including ash) increased for both the savanna-tree and savanna-grass plots one day after the fire in 2002 compared to one day before the fire (Table 2). The unburned forest plots showed no change within the 2 day time period of sampling, and thus the increase in exchangeable $\mathrm{NH}_{4}{ }^{+}$in the burned plots was almost certainly caused by fire. The increase in exchangeable $\mathrm{NH}_{4}{ }^{+}$ was higher for the savanna-tree plots than for the savanna-grass plots, and was only significant for the savanna-tree plots. The increase for the savanna-tree plots was on average $0.23 \mathrm{~g} \mathrm{~m}^{-2}$, or $13 \%$ of the $\mathrm{N}$ in the litter that was burned.

Annual net N mineralization rates during 20022003 showed similar trends as the rates measured during mid-June to mid-August, and were highest in the unburned forest plots $\left(7.8 \mathrm{~g} \mathrm{~m}^{-2} \mathrm{y}^{-1}\right)$, followed by the savanna-tree plots $\left(3.4 \mathrm{~g} \mathrm{~m}^{-2} \mathrm{y}^{-1}\right)$, and lowest in the savanna-grass and dead tree plots $(0.9-$ $1.4 \mathrm{~g} \mathrm{~m}^{-2} \mathrm{y}^{-1}$, Table 3). Average annual $\mathrm{N}$ losses through volatilization (based on 2002 data) and leaching (based on 2002 and 2003 data) were higher in the savanna-tree plots than in the savanna-grass plots, although only significantly so for $\mathrm{N}$ losses 

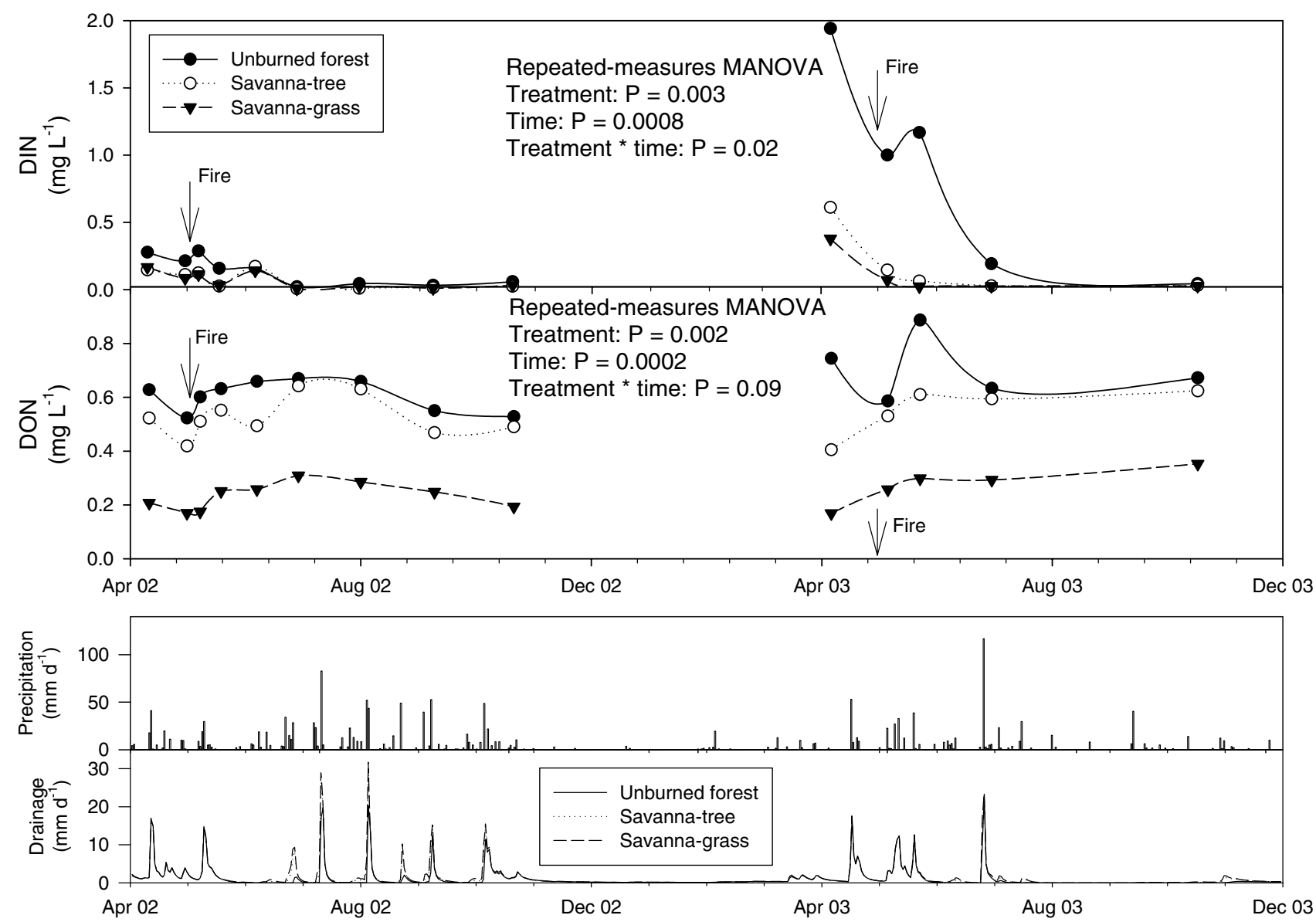

Figure 1. Dissolved inorganic (DIN) and organic (DON) N concentration $\left(\mathrm{mg} \mathrm{l}^{-1}\right)$ in soil solution at 60-cm soil depth, precipitation $\left(\mathrm{mm} \mathrm{d}^{-1}\right)$, and modeled water flux $\left(\mathrm{mm} \mathrm{d}^{-1}\right)$ at $60-\mathrm{cm}$ soil depth for unburned forest, savanna-tree, and savanna-grass plots from April 2002 to December 2003.

through leaching. Nitrogen loss through leaching below $60 \mathrm{~cm}$ soil depth predominantly occurred as DON in all plots, while in the unburned forest plots a substantial amount of $\mathrm{N}$ was lost as DIN as well.

Despite the greater losses through volatilization and leaching, total soil $\mathrm{N}$ pools in the top $15 \mathrm{~cm}$ of the soil were not significantly smaller in the savanna-tree plots than in the savanna-grass plots (Table 3). Of all the plots in the burned units, only the savanna-grass plots had significantly lower total soil $\mathrm{N}$ pools than the unburned forest plots. Interestingly, the dead tree plots had total soil $\mathrm{N}$ pools that were similar to the savanna-tree plots, but showed net $\mathrm{N}$ mineralization rates as low as in the savanna-grass plots.

The cumulative amount of $\mathrm{N}$ leached after 268 days of incubation and potential net $\mathrm{N}$ mineralization expressed per gram total soil $\mathrm{N}$ measured in laboratory incubations were highest in the unburned forest plots, followed by the savanna-tree, dead00, dead95, and dead90 plots, and lowest in the savanna-grass plots (Figure 3A). Potential net N mineralization in the unburned forest, savannatree and dead00 plots were significantly higher than in the dead90 and savanna-grass plots. After 268 days, between $10 \%$ (savanna-grass plots) and $16 \%$ (unburned forest plots) of the total initial soil $\mathrm{N}$ pool was mineralized, and mineralization still continued, although by this point, treatments converged to similar rates (Figure $3 \mathrm{~B}$ ). These results suggest that differences in net $\mathrm{N}$ mineralization among treatments occurred because of differences in the amount of labile $\mathrm{N}$ pools.

Savanna-tree plots showed greater litter N inputs with higher $\mathrm{N}$ concentration than savanna-grass plots. A substantial amount of unburned litter remained in the savanna-tree plots after the fires in 1996 and 2002 (Figure 2). Aboveground litter (weighted average of oak leaf and herbaceous litter) and root $\mathrm{N}$ concentrations were significantly higher in the savanna-tree plots than in the savanna-grass plots (Table 4). 


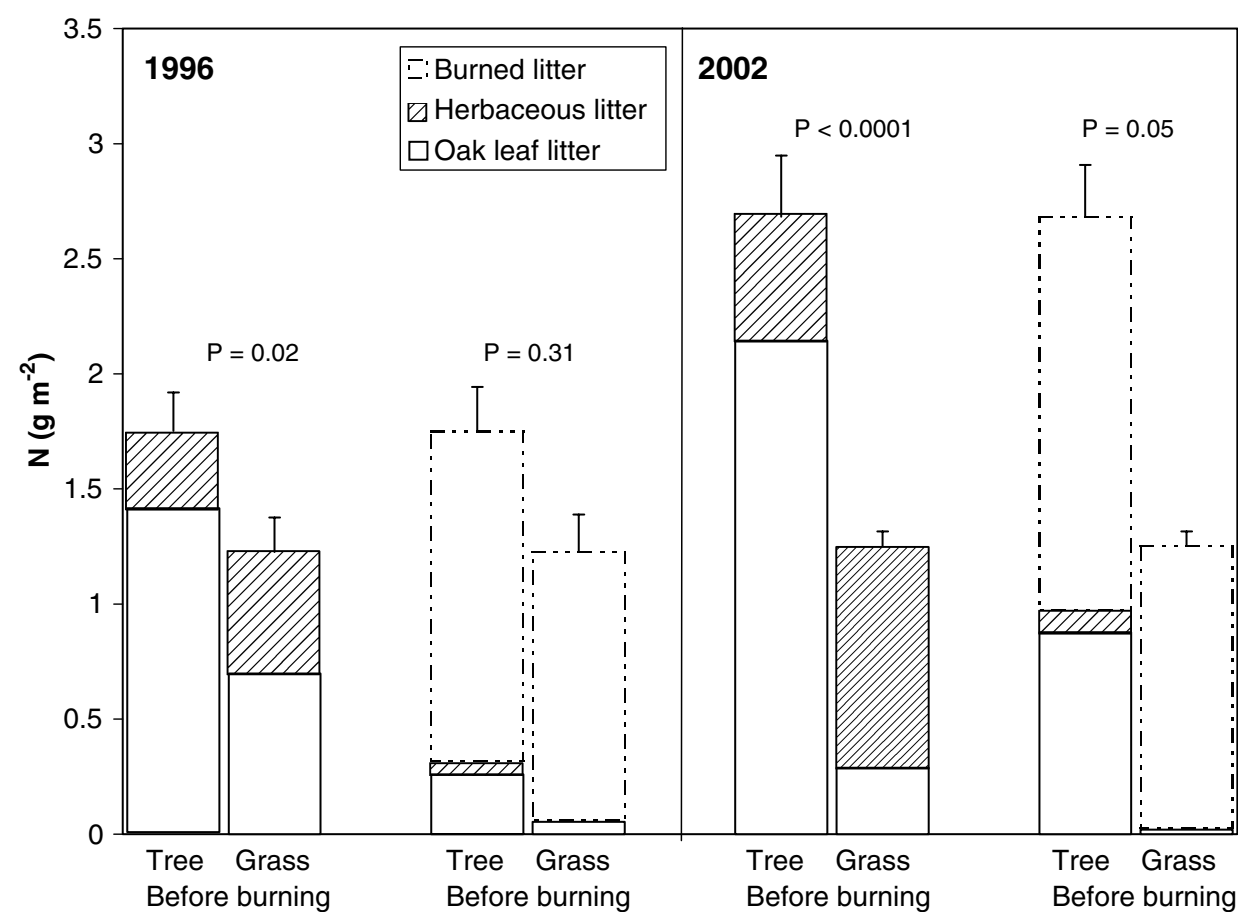

Figure 2. Average N pools in aboveground litter ( $\mathrm{g}$ $\mathrm{m}^{-2}$ ) before burning and after burning, and in burned litter in savanna-tree ('Tree') and savanna-grass ('Grass') plots measured before and after fire events in 1996 and 2002. Error bars are standard errors. Error bars and $P$ values above bars before burning are for total $\mathrm{N}$ pools in litter and above bars after burning for $\mathrm{N}$ in burned litter only.

Table 2. Average Change in Exchangeable $\mathrm{N}\left(\mathrm{g} \mathrm{m}^{-2}\right)$ in the First $5 \mathrm{~cm}$ of the Soil Directly Before and After Burning in 2002

\begin{tabular}{|c|c|c|c|}
\hline Treatment & $\mathrm{NO}_{3}{ }^{-}\left(\mathrm{g} \mathrm{m}^{-2}\right)$ & $\mathrm{NH}_{4}^{+}\left(\mathrm{g} \mathrm{m}^{-2}\right)$ & Total $\left(\mathrm{g} \mathrm{m}^{-2}\right)$ \\
\hline Unburned forest & $-0.007(0.007)^{\mathrm{a}}$ & $-0.002(0.08) \mathrm{a}$ & $-0.009(0.08)^{\mathrm{a}}$ \\
\hline Savanna-tree & $-0.0003(0.0003)^{a}$ & $0.23(0.07)^{\mathrm{b}}$ & $0.23(0.07)^{\mathrm{b}}$ \\
\hline Savanna-grass & $-0.008(0.005)^{\mathrm{a}}$ & $0.06(0.02)^{\mathrm{a}}$ & $0.05(0.02)^{\mathrm{a}}$ \\
\hline
\end{tabular}

Standard error in brackets. Different letters in each column indicate significant differences among treatments $(P<0.05)$ with one-way ANOVA, with post hoc Tukey test.

Table 3. Average Annual Net $\mathrm{N}$ Mineralization, Annual Losses of $\mathrm{N}$ through Leaching and Volatilization and Total Soil N

\begin{tabular}{|c|c|c|c|c|c|c|}
\hline & Unburned forest & Savanna-tree & Savanna-grass & Dead90 & Dead95 & Dead00 \\
\hline $\begin{array}{l}\text { Net } \mathrm{N} \text { mineralization } \\
\qquad\left(\mathrm{g} \mathrm{m}^{-2} \mathrm{y}^{-1}\right)^{\mathrm{a}}\end{array}$ & $7.75(0.55)^{a}$ & $3.42(0.35)^{\mathrm{b}}$ & $0.88(0.06)^{\mathrm{c}}$ & $1.24(0.31)^{\mathrm{C}}$ & $1.01(0.21)^{\mathrm{c}}$ & $1.39(0.26)^{c}$ \\
\hline \multicolumn{7}{|l|}{$\mathrm{N}$ leaching $\left(\mathrm{g} \mathrm{m}^{-2} \mathrm{y}^{-1}\right)^{\mathrm{b}}$} \\
\hline DIN & $0.19(0.07)^{\mathrm{a}}$ & $0.05(0.01)^{\mathrm{b}}$ & $0.04(0.01)^{\mathrm{b}}$ & & & \\
\hline DON & $0.22(0.04)^{\mathrm{a}}$ & $0.22(0.02)^{\mathrm{a}}$ & $0.11(0.01)^{\mathrm{b}}$ & & & \\
\hline Total & $0.41(0.08)^{\mathrm{a}}$ & $0.27(0.03)^{\mathrm{b}}$ & $0.15(0.01)^{\mathrm{c}}$ & & & \\
\hline $\begin{array}{l}N \text { loss through } \\
\text { volatilization }\left(\mathrm{g} \mathrm{m}^{-2} \mathrm{y}^{-1}\right)^{\mathrm{c}}\end{array}$ & & $1.5(0.3)^{\mathrm{a}}$ & $1.2(0.1)^{\mathrm{a}}$ & & & \\
\hline Total soil $\mathrm{N}\left(\mathrm{g} \mathrm{m}^{-2} \mathrm{~d}\right)$ & $105(7)^{a}$ & $90(5)^{a b}$ & $76(4)^{\mathrm{b}}$ & $93(14)^{\mathrm{ab}}$ & $87(5)^{a b}$ & $91(11)^{\mathrm{ab}}$ \\
\hline \multicolumn{7}{|c|}{$\begin{array}{l}\text { Different letters in each row indicate significant differences among treatments }(P<0.05) \text { with one-way ANOVA, with post hoc Tukey test. } \\
\text { Total soil } N \text { for first } 15 \mathrm{~cm} \text {. } \\
\text { Standard errors of means shown in parentheses. } \\
{ }^{a} \text { Annual net } N \text { mineralization based on } 2002-2003 \text { measurements, first } 15 \mathrm{~cm} \text {. } \\
{ }^{b} \text { Annual } N \text { leaching based on } 2002 \text { and } 2003 \text { measurements, below } 60 \mathrm{~cm} \text {. } \\
{ }^{c} N \text { loss through yolatizization bosed on } 2002 \text { measurements }\end{array}$} \\
\hline
\end{tabular}




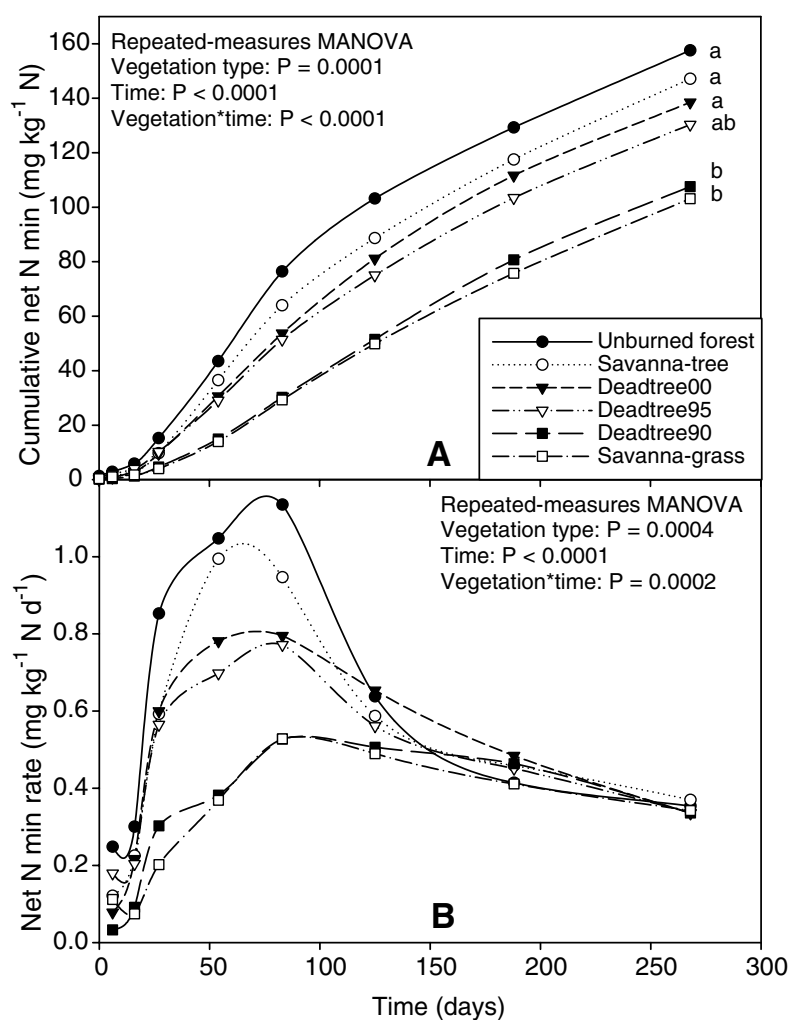

Figure 3. Net $\mathrm{N}$ mineralization $\left(\mathrm{NH}_{4}{ }^{+}+\mathrm{NO}_{3}{ }^{-}\right)$over 268 days in laboratory incubations of soils from unburned forest, savanna-tree, savanna-grass, and dead tree plots. A Cumulative net $\mathrm{N}$ mineralization $\left(\mathrm{mg} \mathrm{kg}^{-1}\right.$ soil $\left.\mathrm{N}\right)$. B Daily net $\mathbf{N}$ mineralization rates. Letters in $\mathbf{A}$ indicate significant differences in final cumulative net $\mathrm{N}$ mineralization (after 268 days) among treatments $(P<0.05)$ with one-way ANOVA, with post hoc Tukey test.

\section{Discussion}

Taken together, our results indicate that the shift from oak dominance in unburned forest sites to $\mathrm{C} 4$ grass dominance in frequently burned sites is a major contributor to the decline in $\mathrm{N}$ cycling that accompanies increasing fire frequency. Although fire reduces $\mathrm{N}$ cycling by promoting losses of $\mathrm{N}$, the shift to C4 grasses likely exacerbates the depression of within-system $\mathrm{N}$ cycling because of low tissue $\mathrm{N}$ concentrations in grasses.

Fire effects on $\mathrm{N}$ losses through volatilization could not explain the higher net $\mathrm{N}$ mineralization rates in the savanna-tree plots than in the savannagrass plots. Annual N losses through volatilization were similar for the savanna-tree and savannagrass plots. Our annual estimates of $\mathrm{N}$ loss through volatilization (where the increase in exchangeable $\mathrm{NH}_{4}{ }^{+}$in the top $5 \mathrm{~cm}$ of the soil directly after fire was subtracted from the total amount of burned $\mathrm{N}$ ) are conservative and thus actual losses may have
Table 4. Average Aboveground Litter and Root N Concentration

\begin{tabular}{lcc}
\hline & $\begin{array}{c}\text { Aboveground } \\
\text { litter N (\%) }\end{array}$ & Root N (\%) \\
\hline Savanna-tree & $1.11(0.04)$ & $0.83(0.03)$ \\
Savanna-grass & $0.64(0.02)$ & $0.70(0.03)$ \\
ANOVA & $<$-value & 0.0001 \\
\hline Standard errors of means shown in parentheses. & \\
\hline
\end{tabular}

been higher, especially for the savanna-tree plots. The increase in soil exchangeable $\mathrm{NH}_{4}{ }^{+}$directly after fire especially occurred in the savanna-tree plots, possibly because of deposition of incompletely burned litter and ash on the top soil (Overby and Perry 1996; Grogan and others 2000), but perhaps also because of increased microbial activity releasing $\mathrm{NH}_{4}{ }^{+}$directly after fire (Fenn and others 1993; Lynds and Baldwin 1998), suggesting that there may have been much less or no return of burned $\mathrm{N}$ to the soil with ash.

Nitrogen losses through leaching could also not explain the higher net $\mathrm{N}$ mineralization rates in the savanna-tree plots than in the savanna-grass plots. Large amounts of $\mathrm{N}$ were lost through leaching below $60-\mathrm{cm}$ soil depth and savanna-tree plots had significantly greater losses than savanna-grass plots. Higher $\mathrm{N}$ losses (that is, DON) in the savanna-tree plots than in the savanna-grass plots through leaching at $60-\mathrm{cm}$ soil depth may have been a consequence of higher net $\mathrm{N}$ mineralization rates in the top-soil where DON is formed as a byproduct (Neff and others 2003). Thus, higher $\mathrm{N}$ losses through leaching in the savanna-tree plots than in the savanna-grass plots put a greater constraint on maintaining relatively high net $\mathrm{N}$ mineralization rates in the savanna-tree plots, especially since these plots already experience high losses of $\mathrm{N}$ through volatilization.

Although fire did not directly alter $\mathrm{N}$ losses through leaching (that is, $\mathrm{N}$ concentrations in soil water at depth did not increase immediately after fire events), annual $\mathrm{N}$ losses through leaching were relatively large. Nitrogen leaching losses caused by low intensity fires are usually small compared to volatilization losses (Johnson and others 1998; Kaye and others 1999). Increased $\mathrm{N}$ availability after fire, as observed here, often results in a burst of plant growth directly after the fire, minimizing leaching losses (Boerner 1982). Inorganic nitrogen leaching losses (DIN, and mostly $\mathrm{NO}_{3}{ }^{-}$) were high because they occurred at times of high water 
drainage and when plants were still inactive (early spring directly after snowmelt), while DON losses were high during the whole growing season suggesting that this DON is of recalcitrant nature that is largely unavailable for plant uptake (Hedin and others 1995; Neff and others 2003). Soils at our sites have low clay and silt content (3\% clay, 3\% silt, Grigal and others 1974) that may have prevented dissolved organic substances from adsorbing onto soil particles while percolating through the soil profile (Neff and others 2003). The high DIN losses during the spring of 2003 may have been a result of increased soil freezing (Fitzhugh and others 2001) during the previous winter when little precipitation (snowfall) occurred to insulate the soil (Figure 1).

Greater net $\mathrm{N}$ mineralization in the savanna-tree plots than in the savanna-grass plots likely resulted from effects of trees on $\mathrm{N}$ cycling, rather than from preferential establishment of trees on more $\mathrm{N}$-rich sites. The relatively quick decline in net $\mathrm{N}$ mineralization without a concurrent decline in total soil $\mathrm{N}$ after tree death, as observed in the dead tree plots, suggests that net $\mathrm{N}$ mineralization was more affected by change in vegetation than by inherent differences between tree and grass plots in soil fertility.

Despite greater $\mathrm{N}$ losses associated with leaching, savanna-tree plots had similar total soil $\mathrm{N}$ pools as savanna-grass plots. One possible mechanism that may have compensated for leaching losses of $\mathrm{N}$ is the uptake of $\mathrm{N}$ from deep soil layers (Jama and others 1998). Rough calculations based on DIN concentrations measured in soil solutions at $60 \mathrm{~cm}$ soil depth suggest that there can be a significant amount of inorganic nitrogen available for plant uptake below $60 \mathrm{~cm}$ soil depth, especially in early spring. For instance, with a DIN concentration of $0.5 \mathrm{mg} \mathrm{l}^{-1}$ in soil solution (measured in spring of 2003, Figure 1) and a soil porosity of $0.4 \mathrm{~m}^{3} \mathrm{~m}^{-3}$ (bulk density of $1.6 \mathrm{~g} \mathrm{~m}^{-3}$, Grigal and others 1974) and assuming that soils are saturated with water (not unlikely directly after snowmelt), there is $0.2 \mathrm{~g}$ $\mathrm{m}^{-2}$ of DIN stored in every meter of the soil profile in early spring. With a soil thickness greater than 2 $m$ (Grigal and others 1974), it becomes clear that in some years a substantial amount of DIN resides in the soil directly after snowmelt that can potentially be taken up through diffusion by trees that have deep roots. Deep roots have been shown to play an important role in nutrient uptake in other ecosystems (Dijkstra and Smits 2002; McCulley and others 2004).

Other sources of increased $\mathrm{N}$ input into the soil that could compensate for losses associated with leaching and reduce differences between tree- and grass-dominated plots in total soil $\mathrm{N}$ pools are $\mathrm{N}$ deposition and $\mathrm{N}$ fixation. Trees that have a higher leaf surface area than grasses may increase inputs of $\mathrm{N}$ by capturing more dry and wet $\mathrm{N}$ deposition, which is then delivered to the soil in throughfall (Weathers and others 2001). Although increased abundance of $\mathrm{N}$-fixing plants has been observed with increased fire frequency and vice versa (Leach and Givnish 1996; Newland and DeLuca 2000), there is no evidence in our frequently burned sites that the tree patches have a greater abundance of $\mathrm{N}$-fixing plants than the open grass patches (D. W. Peterson, unpublished results). Wet atmospheric deposition alone contributes on average $1 \mathrm{~g}$ inorganic $\mathrm{N} \mathrm{m}^{-2} \mathrm{y}^{-1}$ (National Atmospheric Deposition Program) at Cedar Creek, and wet and dry atmospheric $\mathrm{N}$ deposition most likely accounts for most of the $\mathrm{N}$ losses caused by fire in this savanna ecosystem.

The savanna-tree plots likely showed higher net $\mathrm{N}$ mineralization rates than the savanna-grass plots because of higher litter $\mathrm{N}$ concentration (for example, Wedin and Tilman 1990; Evans and others 2001) and labile $\mathrm{N}$ pools in the soil, rather than because of effects of trees on the soil microenvironment (Bernhard-Reversat 1982; Belsky and others 1989; Wilson and Kleb 1996). Differences among plots in in situ net $\mathrm{N}$ mineralization were qualitatively similar to differences observed in laboratory incubations in which temperature and moisture were held constant. Further, higher potential net $\mathrm{N}$ mineralization expressed per unit of total soil $\mathrm{N}$ in the savanna-tree plots than in the savanna-grass plots suggests that differences in net $\mathrm{N}$ mineralization were caused by differences in the quality of the soil $\mathrm{N}$ pool. The relatively large amount of labile $\mathrm{N}$ in the soil in the savanna-tree plots, which decreased rapidly after tree death, further suggest that the presence of oak trees promote higher net $\mathrm{N}$ mineralization than savannagrass plots. In addition to having higher litter $\mathrm{N}$ concentration, the savanna-tree plots may have maintained higher soil labile $\mathrm{N}$ pools by stimulating higher rates of soil $\mathrm{N}$ turnover because of greater inputs of carbon substrates that support greater microbial (including mycorrhizal) activity and turnover (Herman and others 2003), by greater root turnover (Reich and others 2001), or by increasing the input of $\mathrm{N}$ into the labile $\mathrm{N}$ pool via deep root uptake (Jama and others 1998) and subsequent addition to the surface soil with plant litter, extended $\mathrm{N}$ uptake of woody plants from open grassland (Belsky 1994), or via $\mathrm{N}$ deposition (Kellman 1979; Bernhard-Reversat 1982). 
Regardless of how the savanna-tree plots maintain greater soil $\mathrm{N}$ availability and net $\mathrm{N}$ mineralization than the savanna-grass plots, our results suggest that the vegetation composition strongly contributes to variations in $\mathrm{N}$ cycling in systems that are frequently perturbed by fires. Because our results stem from only two burn units with similar fire history, we caution against making broad generalizations about effects of shifts in woody versus herbaceous vegetation on $\mathrm{N}$ cycling in fireperturbed systems. For instance, an increase in $\mathrm{N}$ cycling has been observed after a prescribed burn, removal of trees, and native grass litter addition in a ponderosa pine-bunchgrass ecosystem (Kaye and Hart 1998), possibly because grass litter has higher $\mathrm{N}$ concentration than pine litter in this system. Our study suggests that increased woody canopy openness (transformation from oak to $\mathrm{C} 4$ grass dominance) with frequent fires can reduce $\mathrm{N}$ cycling, potentially restricting the reestablishment of oak seedlings, and likely further reducing plant productivity.

\section{ACKNOWLEDGEMENTS}

This research was supported by the NSF LTER Program (DEB-0080382). We thank Mark Norris and two anonymous reviewers for helpful comments on an earlier draft and Chinelo Njaka and Steve Bauer for field and lab work.

\section{REFERENCES}

Belsky AJ. 1994. Influences of trees on savanna productivity: tests of shade, nutrients, and tree-grass competition. Ecology 75:922-32.

Belsky AJ, Amundson RG, Duxbury JM, Riha SJ, Ali AR, Mwonga SM. 1989. The effects of trees on their physical, chemical, and biological environments in a semi-arid savanna in Kenya. J Appl Ecol 26:1005-24.

Bernhard-Reversat F. 1982. Biogeochemical cycle of nitrogen in a semi-arid savanna. OIKOS 38:321-32.

Blair JM. 1997. Fire, N availability, and plant response in grasslands: a test of the transient maxima hypothesis. Ecology 78:2359-68.

Boerner REJ. 1982. Fire and nutrient cycling in temperate ecosystems. BioScience 32:187-92.

Briggs JM, Knapp AK, Brock BL. 2002. Expansion of woody plants in tallgrass prairie: a fifteen-year study of fire and firegrazing interactions. Am Midl Nat 147:287-94.

Chorover J, Vitousek PM, Everson DA, Esperanza AM, Turner D. 1994. Solution chemistry profiles of mixed-conifer forests before and after fire. Biogeochemistry 26:115-44.

Cook GD. 1994. The fate of nutrients during fires in a tropical savanna. Aust J Ecol 19:359-65.

Daly C, Bachelet D, Lenihan JM, Neilson RP, Parton W, Ojima D. 2000. Dynamic simulation of tree-grass interactions for global change studies. Ecol Appl 10:449-69.
Dijkstra FA, Smits MM. 2002. Tree species effects on calcium cycling: the role of calcium uptake in deep soils. Ecosystems 5:385-98.

Dodds WK, Blair JM, Henebry GM, Koelliker JK, Ramundo R, Tate CM. 1996. Nitrogen transport from tallgrass prairie watersheds. J Environ Qual 25:973-81.

Evans RD, Rimer R, Sperry L, Belnap J. 2001. Exotic plant invasion alters nitrogen dynamics in an arid grassland. Ecol Appl 11:1301-10.

Eviner VT, Chapin FS III. 2004. Functional matrix: a conceptual framework for predicting multiple plant effects on ecosystem processes. Annu Rev Ecol Syst 34:455-85.

Federer CA. 1995. BROOK90: a simulation model for evaporation, soil water, and streamflow. Computer freeware and documentation. Durham (NH): USDA Forest Service.

Fenn ME, Poth MA, Dunn PH, Barro SC. 1993. Microbial N and biomass, respiration and $\mathrm{N}$ mineralization in soils beneath two chaparral species along a fire-induced age gradient. Soil Biol Biochem 25:457-66.

Fitzhugh RD, Driscoll CT, Groffman PM, Tierney GL, Fahey TJ, Hardy JP. 2001. Effects of soil freezing disturbance on soil solution nitrogen, phosphorus, and carbon chemistry in a northern hardwood ecosystem. Biogeochemistry 56:215-38.

Fynn RWS, Haynes RJ, O'Connor TG. 2003. Burning causes long-term changes in soil organic matter content of a South African grassland. Soil Biol Biochem 35:677-87.

Grigal DF, Chamberlain LM, Finney HR, Wroblewski DV, Gross ER. 1974. Soils of the Cedar Creek natural history area. Miscellaneous report 123. St. Paul (MN): University of Minnesota Agricultural Experiment Station. p 47.

Grogan P, Bruns TD, Chapin FS III. 2000. Fire effects on ecosystem nitrogen cycling in a Californian bishop pine forest. Oecologia 122:537-44.

Hedin LO, Armesto JJ, Johnson AH. 1995. Patterns of nutrient loss from unpolluted, old-growth temperate forests-evaluation of biogeochemical theory. Ecology 76:493-509.

Herman DJ, Halverson LJ, Firestone MK. 2003. Nitrogen dynamics in an annual grassland: oak canopy, climate, and microbial population effects. Ecol Appl 13:593-604.

Hobbie SE. 1992. Effects of plant species on nutrient cycling. Trends Ecol Evol 7:336-9.

Hobbs NT, Schimel DS. 1984. Fire effects on nitrogen mineralization and fixation in mountain shrub and grassland communities. J Range Manage 37:402-5.

Houghton RA, Hackler JL, Lawrence KT. 2000. Changes in terrestrial carbon storage in the United States. 2: the role of fire and fire management. Glob Ecol Biogeogr 9:145-70.

Huddle JA, Pallardy SG. 1996. Effects of long-term annual and periodic burning on tree survival and growth in a Missouri Ozark oak-hickory forest. For Ecol Manage 82:1-9.

Hurtt GC, Pacala SW, Moorcroft PR, Caspersen J, Shevliakova E, Houghton RA, Moore B III. 2002. Projecting the future of the US carbon sink. Proc Natl Acad Sci 99:1389-94.

Irving FD. 1970. Field instruction in prescribed burning techniques at the University of Minnesota. In: Proc Tall Timbers Fire Ecol Conf 10:323-31.

Jama B, Buresh RJ, Ndufa JK, Shepherd KD. 1998. Vertical distribution of roots and soil nitrate: tree species and phosphorus effects. Soil Sci Soc Am J 62:280-6.

Johnson DW, Susfalk RB, Dahlgren RA, Klopatek JM. 1998. Fire is more important than water for nitrogen fluxes in semi-arid forests. Environ Sci Pol 1:79-86. 
Kaye JP, Hart SC. 1998. Ecological restoration alters nitrogen transformations in a ponderosa pine-bunchgrass ecosystem. Ecol Appl 8:1052-60.

Kaye JP, Hart SC, Cobb RC, Stone JE. 1999. Water and nutrient outflow following the ecological restoration of a ponderosa pine-bunchgrass ecosystem. Restor Ecol 7:252-61.

Kellman M. 1979. Soil enrichment by neotropical savanna trees. J Ecol 67:565-77.

Leach MK, Givnish TJ. 1996. Ecological determinants of species loss in remnant prairies. Science 273:1555-8.

Lynds GY, Baldwin IT. 1998. Fire, nitrogen, and defensive plasticity in Nicotiana attenuata. Oecologia 115:531-40.

McCulley RL, Jobbagy EG, Pockman WT, Jackson RB. 2004. Nutrient uptake as a contributing explanation for deep rooting in arid and semi-arid ecosystems. Oecologia 141:620-8.

Neff JC, Chapin FS III, Vitousek PM. 2003. Breaks in the cycle: dissolved organic nitrogen in terrestrial ecosystems. Front Ecol Environ 1:205-11.

Newland JA, DeLuca TH. 2000. Influence of fire on native nitrogen-fixing plants and soil nitrogen status in ponderosa pine-Douglas-fir forests in western Montana. Can J For Res 30:274-82.

Ojima DS, Schimel DS, Parton WJ, Owensby CE. 1994. Longand short-term effects of fire on nitrogen cycling in tallgrass prairie. Biogeochemistry 24:67-84.

Overby ST, Perry HM. 1996. Direct effects of prescribed fire on available nitrogen and phosphorus in an Arizona chaparral watershed. Arid Soil Res Rehabil 10:347-57.

Peterson DW, Reich PB. 2001. Prescribed fire in oak savanna: fire frequency effects on stand structure and dynamics. Ecol Appl 11:914-27.

Raison RJ, Khanna PK, Woods PV. 1985. Transfer of elements to the atmosphere during low-intensity prescribed fires in three Australian subalpine Eucalypts forests. Can J For Res 15:657-64.
Reich PB, Peterson DW, Wedin DA, Wrage K. 2001. Fire and vegetation effects on productivity and nitrogen cycling across a forest-grassland continuum. Ecology 82:1703-19.

Schoch P, Binkley D. 1986. Prescribed burning increased nitrogen availability in a mature loblolly pine stand. For Ecol Manage 14:13-22.

Scholes RJ, Archer SR. 1997. Tree-grass interactions in savannas. Annu Rev Ecol Syst 28:517-44.

Tilman D, Reich P, Phillips H, Menton M, Patel A, Vos E, Peterson D, Knops J. 2000. Fire suppression and ecosystem carbon storage. Ecology 81:2680-5.

Turner CL, Blair JM, Schartz RJ, Neel JC. 1997. Soil N and plant responses to fire, topography, and supplemental $\mathrm{N}$ in tallgrass prairie. Ecology 78:1832-43.

Von Ende CN. 2001. Repeated-measures analysis: growth and other time-dependent measures. In: Scheiner SM, Gurevitch J, Eds. Design and analysis of ecological experiments. Oxford: Oxford University Press. p 134-57.

Wardle DA, Hörnberg G, Zackrisson O, Kalela-Brundin M, Coomes DA. 2003. Long-term effects of wildfire on ecosystem properties across an island area gradient. Science 300 : 972-75.

Weathers KC, Cadenasso ML, Pickett STA. 2001. Forest edges as nutrient and pollutant concentrators: potential synergisms between fragmentation, forest canopies, and the atmosphere. Conserv Biol 15:1506-14.

Wedin DA, Tilman D. 1990. Species effects on nitrogen cycling: a test with perennial grasses. Oecologia 84:433-41.

Wilson SD, Kleb HR. 1996. The influence of prairie and forest vegetation on soil moisture and available nitrogen. Am Midl Nat 136:222-31.

Wright RF. 1976. The impact of forest fire on the nutrient influxes to small lakes in northeastern Minnesota. Ecology 57:649-63. 